\title{
RESISTENCE OF RADISH BIOTYPES TO IODOSUlFURON AND Alternative Control ${ }^{1}$
}

\author{
Resistência de Biótipos de Nabo ao Herbicida Iodosulfurom e Controle Alternativo
}

CECHIN, J. ${ }^{2}$, VARGAS, L. ${ }^{3}$, AGOSTINETTO, D. ${ }^{2}$, ZIMMER, V. ${ }^{2}$, PERTILE, M. ${ }^{2}$, and GARCIA, J.R. ${ }^{2}$

\begin{abstract}
The repetitive use of iodosulfuron for the control of weeds in winter cereals in the south of Brazil has favored the emergence of resistant Raphanus sativus biotypes. The objective of this study was to evaluate: the response of Raphanus sativus biotypes susceptible and resistant to different dosages of iodosulfuron; the control of biotypes with alternative registered herbicides for the control of the species in crops of wheat, corn and soybean; and the existence of cross-resistance of the biotypes. Thus, four experiments were done in a greenhouse, with a completely randomized design and four replicates. The experimental units were composed of vases with a volumetric capacity of $0.75 \mathrm{~L}$ filled with substrate, containing a plant each. For the dose-response curve, three biotypes (factor A) and nine doses of the iodosulfuron herbicide (factor B) were used. For the alternative control, the recommendation was herbicides in pre or postemergence of the crops, and the crossedresistance was evaluated by using herbicides that inhibit the ALS enzyme of different chemical groups. The analyzed variables were control and shoot dry matter. GR $_{50}$ of the susceptible biotype $\left(B_{1}\right)$ was $0.11 \mathrm{~g}$ a.i. ha ${ }^{-1}$, whereas $G_{50}$ of resistant biotypes $\left(B_{4}\right.$ and $\left.B_{13}\right)$ was 102.9 and $86.8 \mathrm{~g}$ a.i. ha ${ }^{-1}$ of the iodosulfuron herbicide, respectively. The resistant biotypes presented crossed resistance to herbicides that inhibit the ALS enzyme, where the control can be efficient with the use of herbicides with different action mechanisms.
\end{abstract}

Keywords: Raphanus sativus, dose-response, acetolactate synthase, weed.

RESUMO - O Uso repetido do herbicida iodosulfurom para controle de plantas daninhas em cereais de inverno no Sul do Brasil favoreceu o surgimento de biótipos de Raphanus sativus resistentes. O objetivo deste estudo foi avaliar: a resposta de biótipos de Raphanus sativus suscetivel $e$ resistentes a diferentes doses do herbicida iodosulfurom; o controle dos biótipos com herbicidas alternativos registrados para controle da espécie nas culturas de trigo, milho e soja; e a existência de resistência cruzada dos biótipos. Assim, foram conduzidos quatro experimentos em casa de vegetação, em delineamento inteiramente casualizado com quatro repetições. As unidades experimentais constituíram-se de vasos com capacidade volumétrica de 0,75 L preenchidos com substrato, contendo uma planta cada. Para a curva de dose-resposta foram utilizados três biótipos (fator A) e nove doses do herbicida iodosulfurom (fator B). Para o controle alternativo, foram preconizados herbicidas na pré e pós-emergência das culturas, e a resistência cruzada foi avaliada utilizando herbicidas inibidores da enzima ALS de diferentes grupos quimicos. As variáveis analisadas foram controle e massa da matéria seca da parte aérea. $A G R_{50}$ do biótipo suscetivel $\left(B_{1}\right)$ foi de $0,11 \mathrm{~g}$ i.a. ha ${ }^{-1}$, enquanto a $G R_{50}$ dos biótipos resistentes $\left(B_{4}\right.$ e $\left.B_{13}\right)$ foi de 102,9 e $86,8 \mathrm{~g}$ i.a. ha $\mathrm{h}^{-1}$ do herbicida iodosulfurom, respectivamente. Os biótipos resistentes apresentaram resistência cruzada a herbicidas inibidores da enzima ALS, onde o controle pode ser eficiente com a utilização de herbicidas com mecanismos de ação distintos.

Palavras-chave: Raphanus sativus, dose-resposta, acetolactato sintase, planta daninha.

1 Recebido para publicação em 10.5.2015 e aprovado em 1.12.2015.

2 Universidade Federal de Pelotas (UFPel), Pelotas-RS, Brazil, <joaneicechin@yahoo.com.br>; ${ }^{3}$ Embrapa Trigo, Passo Fundo-RS, Brazil. 


\section{INTRODUCTION}

Raphanus sativus (radish) is a type of soil coverage that happens in autumn/winter which is highly used in agricultural systems of the south of Brazil due to its fast growth and because it suppresses the growth of weeds (Balbinot Jr et al., 2007). Although it is very important, radish is one of the main dicotyledon weeds when present in the winter and summer crops, resulting in significant losses in the final yield of the crops (Vargas \& Roman, 2005; Bianchi et al., 2011).

The control of radish with herbicides that inhibit the ALS enzyme is the main management tool due to its high efficiency and selectivity to winter crops (Vargas \& Roman, 2005). These herbicides act in the first enzyme of the synthesis rout of the valine, leucine and isoleucine side chain amino acids, where there is a blockage of cell division and DNA synthesis (Duggleby et al., 2008). Although it is efficient, the dependence on a single action mechanism enabled the emergence of resistance cases (Walsh et al., 2007). In Brazil, the first records of resistance of $R$. sativus biotypes to herbicides inhibitors of the ALS enzyme, such as the metsulfuron-methyl, chlorimuron-ethyl, imazethapyr, cloransulammethyl and nicosulfuron, date back to 2001 . Years later, biotypes of $R$. sativus were found with crossed resistance to herbicides inhibitors of the ALS enzyme in Argentina and Chile (Heap, 2015).

The resistance provides the biotypes with survival and capacity of reproducing after being submitted to a dosage of herbicide that would be lethal on the other individuals of the same population (Vargas et al., 2009). The survival of biotypes to herbicides can happen due to factors related to the target-site (associated with gene mutations or enzyme overexpression) or due to the non-targetsite of the herbicide (increase in the metabolization, compartmentalization or reduction of absorption and/or translocation of the herbicide), affecting the efficacy of the herbicide (Délye, 2013).

Among the alterations caused by the resistance is the increase of the necessary dosage to control these biotypes, which can be obtained through curves of dose-response, which allow to determine the $\mathrm{C}_{50}$ (control of $50 \%$ ) and $\mathrm{GR}_{50}$ (reduction of $50 \%$ of the dry matter), in addition to the resistance factor (RF) of the biotypes (Christoffoleti, 2002). The increase of the herbicide dosage in radish biotypes resistant to herbicides that inhibit the ALS enzyme may make its use impracticable, and the use of alternative herbicides for the control may be recommended in order to minimize the negative effects they have on the crops (Monjardino et al., 2003; Pandolfo et al., 2013), besides avoiding the selection of new resistant biotypes (Oliveira Neto et al., 2010).

The intensification of control failure on radish populations with iodosulfuron leads us to believe that there are biotypes resistant to this and other herbicides that inhibit the ALS enzyme, calling for the use of higher control doses when compared to susceptible biotypes. Therefore, the objective of this study was to evaluate the response of Raphanus sativus biotypes susceptible and resistant to different dosages of iodosulfuron; evaluate the control of these biotypes with alternative herbicides recommended for the control of the species in the crops of wheat, corn and soybean; and to evaluate the existence of a cross resistance of the tested biotypes.

\section{MATERIAL AND METHODS}

Thus, to carry out this study, four experiments were done in a greenhouse, with a completely randomized design and four replicates, containing a plant per plastic vase. First, werecollected seeds of radish from crops of wheat in the north and northwest regions of Rio Grande do Sul that survived the application of iodosulfuron. In total, 16 biotypes were collected; the seeds contained in each sample were from one plant, and they were identified and georeferenced through their geodetic coordinates.

\section{Screening}

The seeds of the biotypes were sown in trays and, after emergence, the plants were transplanted to plastic vases with a volumetric capacity of $0.75 \mathrm{~L}$, containing soil of the type 
Red Yellow Argisol and GerminaPlant ${ }^{\circledR}$ substrate in the proportion 2:1. The analysis of the soil showed $\mathrm{pH}$ in water $=5.6$; $\mathrm{CTC}_{\mathrm{pH} 7}=7.2 \mathrm{cmol}_{\mathrm{c}} \mathrm{dm}^{-3}$; organic matter $=1.5 \%$; clay $=16 \%$; texture $=4 ; \mathrm{Ca}=4,1 \mathrm{cmol}_{\mathrm{c}} \mathrm{dm}^{-3}$; $\mathrm{Mg}=1.1 \mathrm{cmol}_{\mathrm{c}} \mathrm{dm}^{-3} ; \mathrm{Al}=1.8 \mathrm{cmol}_{\mathrm{c}} \mathrm{dm}^{-3}$; $\mathrm{P}=6.5 \mathrm{mg} \mathrm{dm}^{-3}$; and $\mathrm{K}=0.15 \mathrm{cmol}_{\mathrm{c}} \mathrm{dm}^{-3}$. The correction of fertility was done before the mixture with the substrate, according to the recommendations for the radish crop.

The biotypes were submitted to the application of the iodosulfuron herbicide in the maximum registered dose for the wheat crop, corresponding to $5.0 \mathrm{~g}$ a.i. ha ${ }^{-1}$, to which was added the spreader-sticker (Hoefix) in the dose of $0.3 \%$ of spray (Agrofit, 2015) when the plants reached a vegetative stage of 3-4 leaves.

The herbicide was applied using the backpack sprayer, pressured at $\mathrm{CO}_{2}$, calibrated to provide spray volume of $120 \mathrm{~L} \mathrm{ha}^{-1}$, equipped with spray nozzles in the form of a fan 110.02, with a space of $50 \mathrm{~cm}$ among each other.

The evaluation of the visual control was done 28 days after the application of the treatment (DAA), adopting the percentage scale in which zero (0) and one hundred (100) corresponded to the absence of damage and complete death of the plants, respectively (Frans \& Crowley, 1986). The choice of the susceptible biotypes was done by the greatest control, and the resistant ones by the smallest control.

\section{Dose-response curve}

To determine the dose-response curve of the iodosulfuron herbicide, a study was carried out in a greenhouse, using an entirely randomized experimental design with four replicates; the experimental units, the establishment, the conduction of the plants and the application of the herbicide happened under the same conditions described in the screening.

The treatments were arranged in a factorial design in which factor $A$ was composed of radish biotypes $\left(\mathrm{B}_{1}, \mathrm{~B}_{4}\right.$ e $\left.\mathrm{B}_{13}\right)$ and factor $B$ of doses of iodosulfuron. For the susceptible biotype $\left(\mathrm{B}_{1}\right)$ the used dosages were $0,6.25,12.5,25,50,100,200,400$ and $800 \%$; for the resistant biotypes $\left(\mathrm{B}_{4}\right.$ e $\left.\mathrm{B}_{13}\right)$ the dosages used were $0,50,100,200,400,800$, $1.600,3.200$ and $6.400 \%$ of the recommended dose of iodosulfuron for the control of radish (3.5 g a.i. ha ${ }^{-1}$ ), to which the spreader-sticker (Hoefix) was added in the doses of $0.3 \%$ of spray (Agrofit, 2015).

The variables evaluated were visual control and shoot dry matter (SDM) 28 days after application (DAA). The SDM was determined by drying the vegetable material in an oven with forced air circulation at $60{ }^{\circ} \mathrm{C}$ until it reached a constant mass, being expressed in g per plant.

The data obtained was analyzed as to its homoscedasticity and then submitted to the variance analysis by the $\mathrm{F}$ test $(\mathrm{p} \leq 0.05)$. The data was adjusted to the non-linear regression model of the logistic type, using the SigmaPlot 12.0 (Sigmaplot, 2012) software; the values of $\mathrm{C}_{50}$ and $\mathrm{GR}_{50}$ were calculated from the parameters of the equation (Seefeldt et al., 1995), to which is related the response of the plant with the dose of the herbicide. The values were adjusted to the logistic type sigmoidal regression equation: $\mathrm{y}=\mathrm{a}$ / $\left[1+\left(\mathrm{x} / \mathrm{x}_{50}\right)^{\mathrm{b}}\right]$, in which: $\mathrm{y}=$ percentage of visual control or SDM; $x=$ dose of the herbicide; and $a, x_{50}$ and $b=$ equation parameters, being $a$ the difference between the maximum and minimum points of the curve; $x_{50}$, the dose that provides $50 \%$ of the variable response; and $b$, the curve declivity.

The resistance factor $(\mathrm{RF})$ was calculated by the ration between $\mathrm{C}_{50}$ or $\mathrm{GR}_{50}$ of the resistant biotype and its corresponding susceptible biotype.

\section{Alternative control}

Three studies in greenhouse were done for an alternative control. The experimental units, the establishment and conduction of plants, the application of the herbicides, the application stage and the variables analyzed were the same as described in the screening study, with the addition of a visual control evaluation at 14 DAA.

The treatments used recommend chemical management strategies considering the dissecting operation and the management of the weed in the postemergence state of the 
wheat, corn and soybean crops, considering the selectivity of the herbicide inside each crop. The herbicides used in the pre-sowing of the cultures were: glyphosate, in the dosage of 720 g a.e. ha-1; glufosinate ammonium, in the dosage of $400 \mathrm{~g}$ a.i. $\mathrm{ha}^{-1}$; paraquat, in the dosage of $400 \mathrm{~g}$ a.i. ha ${ }^{-1}$; diuron+paraquat, in the dosage of $200+400 \mathrm{~g}$ a.i. ha $\mathrm{ha}^{-1}$; and saflufenacil, in the dosage of $49 \mathrm{~g}$ a.i. ha ${ }^{-1}$.

The herbicides used in the postemergence management in the wheat crops were: metsulfuron-methyl, in the dosage of $4.0 \mathrm{~g}$ a.i. ha ${ }^{-1}$; bentazon, in the dosage of $720 \mathrm{~g}$ a.i. ha ${ }^{1}$; metribuzin, in the dosage of $144 \mathrm{~g}$ a.i. ha ${ }^{-1}$; and 2,4-D amine, in the dosage of $1.005 \mathrm{~g}$ a.e. ha ${ }^{-1}$. The herbicides used in the postemergence management in the corn crops were: mesotrione, in the dosage of $192 \mathrm{~g}$ a.i. ha- ${ }^{-1}$; atrazine, in the dosage of $2.500 \mathrm{~g}$ a.i. ha ${ }^{-1}$; tembotrione, in the dosage of $76 \mathrm{~g}$ a.i. ha ${ }^{-1}$; and nicosulfuron, in the dosage of $60 \mathrm{~g}$ a.i. $\mathrm{ha}^{-1}$. The herbicides used in the postemergence management in the soybean crops were: clorimurom-ethyl, in the dosage of $20 \mathrm{~g}$ a.i. ha ${ }^{-1}$; fomesafen, in the dosage of $250 \mathrm{~g}$ a.i. ha ${ }^{-1}$; imazethapyr, in the dosage of $106 \mathrm{~g}$ a.i. $\mathrm{ha}^{-1}$; and cloransulam-methyl, in the dosage of $30 \mathrm{~g}$ a.i. $\mathrm{ha}^{-1}$. An adjuvant or spreader-sticker was added, according to the manufacturer's recommendation (Agrofit, 2015).

The data obtained was analyzed as to its homoscedasticity and submitted to the variance analysis by the $F$ test $(p \leq 0.05)$. For the biotypes factor, the data was compared by the $t$ test $(p \leq 0.05)$ and, for the herbicide treatments, they were compared by the Duncan test $(\mathrm{p} \leq 0.05)$.

\section{Crossed resistance}

Regarding crossed resistance, a study was carried out in a greenhouse. The experimental units, the establishment and conduction of plants, the application of the herbicides, the application stage and the methodology used to evaluate each variable were the same as described in screening.

The herbicide treatments recommend the use of at least one herbicide for each chemical group of inhibitors of the ALS enzyme in the different radish biotypes $\left(\mathrm{B}_{1}, \mathrm{~B}_{4}\right.$ e $\left.\mathrm{B}_{13}\right)$. The herbicides used were: iodosulfuron, in the dose of $3.5 \mathrm{~g}$ a.i. ha- ${ }^{-1}$ (sulfonylurea); metsulfuronmethyl, in the dosage of $4.0 \mathrm{~g}$ a.i. $\mathrm{ha}^{-1}$ (sulfonylurea); imazethapyr, in the dosage of $106 \mathrm{~g}$ a.i. ha-1 (imidazolinone); cloransulammethyl, in the dosage of $40 \mathrm{~g}$ a.i. ha ${ }^{-1}$ (triazolopyrimidine); bispyribac sodium, in the dosage of $50 \mathrm{~g}$ a.i. ha ${ }^{-1}$ (pyrimidinyl thiobenzoate); and flucarbazone-sodium, in the dosage of $21 \mathrm{~g}$ a.i. ha $\mathrm{h}^{-1}$ (sulfonyl aminocarbonyl thiazolinone), which were compared to the control without application. An adjuvant or spreader-sticker was added, according to the manufacturer's recommendation.

The data obtained was analyzed as to its homoscedasticity and submitted to the variance analysis by the $\mathrm{F}$ test $(\mathrm{p} \leq 0.05)$. The biotypes factor was compared by the $t$ test $(p \leq 0.05)$ and, the herbicide treatments were compared by the Duncan test ( $\mathrm{p} \leq 0.05)$.

\section{RESULTS AND DISCUSSION}

The results and discussion will be presented obeying the sequence of activities presented in material and methods.

\section{Screening}

The results have shown the existence of two susceptible biotypes and 14 biotypes resistant to the iodosulfuron herbicide at 28 DAA (non-sampled data). The selected biotypes were: $\mathrm{B}_{1}$ (susceptible to the herbicide, original from the city of Três de Maio-RS), which presented $99 \%$ of control; and $\mathrm{B}_{4}$ and $\mathrm{B}_{13}$, considered resistant, original rom the city of Três de Maio and Boa Vista do Cadeado-RS, respectively, with $1 \%$ control (non-sampled data). Later on, each biotype was duly classified as to its taxonomy and deposited at the herbarium PEL of the Department of Botany, belonging to the Federal University of Pelotas (UFPel), under the numbers 26.495 $\left(\mathrm{B}_{1}\right), 26.496\left(\mathrm{~B}_{4}\right)$ and $26.497\left(\mathrm{~B}_{13}\right)$.

\section{Dose-response curve}

The variance analysis indicated interaction among the biotypes factors and doses of iodosulfuron; the control data and the 
SDM were adjusted to the logistic type sigmoid curves (Figure 1). The control results, obtained at $28 \mathrm{DAA}$, showed that $\mathrm{C}_{50}$ of the susceptible biotype $\left(B_{1}\right)$ and the resistant biotypes $\left(\mathrm{B}_{4}\right.$ and $\left.\mathrm{B}_{13}\right)$ was $0.22,19.5$ and $55.5 \mathrm{~g}$ a.i. ha ${ }^{-1}$, respectively (Table 1 ). These doses are 33 and 274 times superior to the one recommended for the iodosulfuron herbicide, which makes its use impracticable for the control of resistant radish. Based on the values of $\mathrm{C}_{50}$, a resistance factor $(\mathrm{RF})$ was calculated for the biotypes $B_{4}$ and $B_{13}$, which was 89 and 252 , respectively, at 28 DAA (Table 1). Similar results were found by Yu et al. (2012) in biotypes of Raphanus raphanistrum submitted to the application of chlorsulfuron, in which the RF was 131.

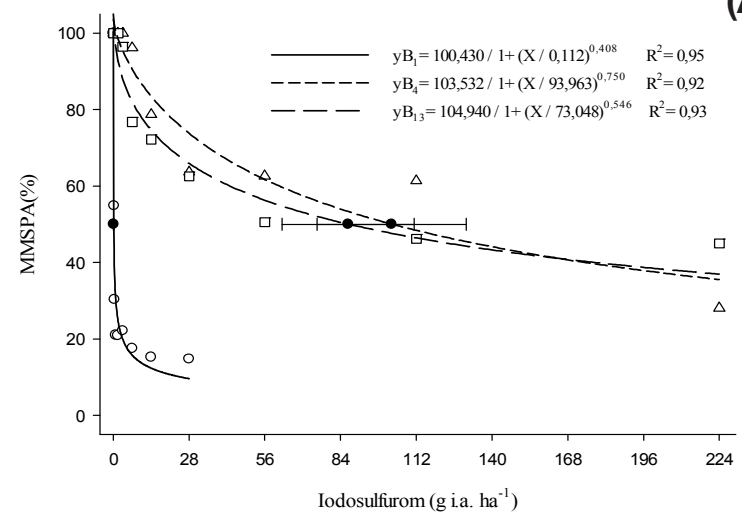

(A)
Regarding the SDM results, it was seen that the accumulation was inversely proportional to the dosage of the herbicide (Figure 1B). For the susceptible biotype $\left(B_{1}\right)$, $\mathrm{GR}_{50}$ was $0.11 \mathrm{~g}$ a.i. ha ${ }^{-1}$, whereas $\mathrm{GR}_{50}$ of resistant biotypes $\left(\mathrm{B}_{4}\right.$ and $\left.\mathrm{B}_{13}\right)$ was 102.9 and $86.8 \mathrm{~g}$ a.i. ha $^{-1}$, respectively, showing the need for elevated doses of the herbicide to provide a $50 \%$ reduction of the SDM, causing an elevated $\mathrm{RF}$ (Table 1). The results corroborate the ones found in biotypes of $R$. sativus resistant to metsulfuron-methyl, in which $\mathrm{GR}_{50}$ was $7.2 \mathrm{~g}$ a.i. ha ${ }^{-1}$, resulting in RF of 144 (Pandolfo et al., 2013).

The resistance levels of tested biotypes were elevated for the iodosulfuron herbicide

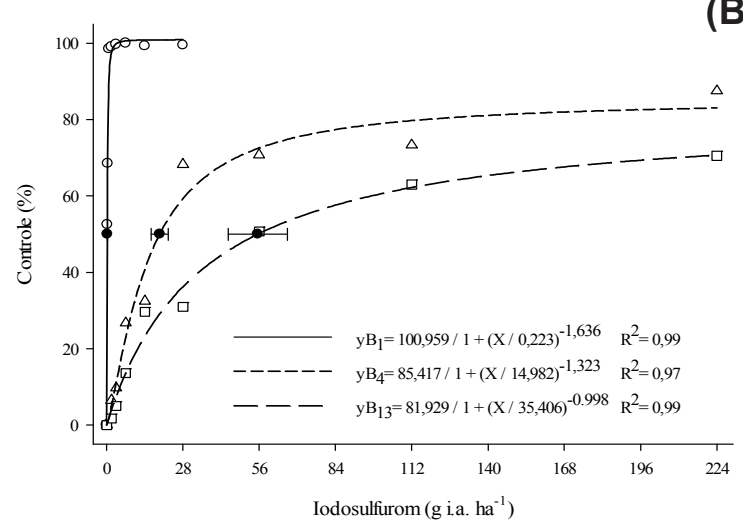

The open symbols represent the average values of four repetitions, and the closed symbols and the horizontal bars represent the confidence intervals for the doses that cause $50 \%$ of the control or $50 \%$ reduction of the SDM.

Figure 1 - Visual control (\%) (A) and shoot dry matter (SDM in \%) (B) of biotypes of susceptible $\left(\mathrm{B}_{1}\right)$ and resistant $\left(\mathrm{B}_{4}\right.$ e $\left.\mathrm{B}_{13}\right)$ Raphanus sativus submitted to doses of iodosulfuron at 28 days after application of the treatments (DAA). Capão do Leão-RS, 2014.

Table 1 - Values of $\mathrm{C}_{50}$ and $\mathrm{GR}_{50}$ with confidence interval (CI) and resistance factor (RF) of biotypes of Raphanus sativus susceptible $\left(\mathrm{B}_{1}\right)$ and resistant $\left(\mathrm{B}_{4}\right.$ and $\left.\mathrm{B}_{13}\right)$ to iodosulfuron, at 28 days after application of the treatments (DAA). Capão do Leão-RS, 2014

\begin{tabular}{|c|c|c|c|}
\hline \multirow{2}{*}{ Biotype } & \multicolumn{2}{|c|}{$\mathrm{C}_{50}$ or $\mathrm{GR}_{50}{ }^{1}$} & \multirow{2}{*}{ Resistance factor ${ }^{2 /}(\mathrm{RF})$} \\
\hline & g i.a. ha $^{-1}$ & $95 \mathrm{CI}$ & \\
\hline \multicolumn{4}{|c|}{$\mathrm{C}_{50}$} \\
\hline Susceptible $\left(\mathrm{B}_{1}\right)$ & 0.22 & $0.24-0.20$ & - \\
\hline Resistant $\left(\mathrm{B}_{4}\right)$ & 19.50 & $24.64-16.37$ & 89.00 \\
\hline Resistant $\left(\mathrm{B}_{13}\right)$ & 55.50 & $66.62-44.38$ & 252.00 \\
\hline \multicolumn{4}{|c|}{$\mathrm{GR}_{50}$} \\
\hline Susceptible $\left(\mathrm{B}_{1}\right)$ & 0.11 & $0.19-0.03$ & - \\
\hline Resistant $\left(\mathrm{B}_{4}\right)$ & 102.90 & $130.54-75.26$ & 935 \\
\hline Resistant $\left(\mathrm{B}_{13}\right)$ & 86.80 & $111.21-62.39$ & 789 \\
\hline
\end{tabular}

${ }^{1 /} \mathrm{C}_{50}$ or $\mathrm{GR}_{50}=$ necessary dosage to obtain control of $50 \%$ or reduction of $50 \%$ of the SDM. ${ }^{2 /} \mathrm{RF}$ obtained by the division of the $\mathrm{C}_{50}$ or $\mathrm{GR}_{50}$ of the resistant biotype by $\mathrm{C}_{50}$ or $\mathrm{GR}_{50}$ of the susceptible biotype. 
when compared to the susceptible biotype $\left(B_{1}\right)$, which shows the need for alternative strategies for the management of the prevention and to avoid the spread of resistance.

\section{Alternative control}

The results of the variance analysis have shown that there was a significant difference for all the analyzed variables, with interaction between the factors biotypes and herbicides (Tables 2, 3 and 4).

The control at 14 DAA was above $90 \%$ in all tested biotypes $\left(\mathrm{B}_{1}, \mathrm{~B}_{4}\right.$ and $\left.\mathrm{B}_{13}\right)$, except for the metsulfuron-methyl herbicide applied in resistant biotypes $\left(\mathrm{B}_{4}\right.$ and $\left.\mathrm{B}_{13}\right)$, where the control was of $5 \%$ and $16 \%$, respectively (Table 2). All recommended herbicides for the desiccation were efficient and are considered options for the control of the resistant radish. Agostinetto et al. (2009) reported control above $97 \%$ in radish when glyphosate was used in the dose of $1.440 \mathrm{~g}$ a.e. ha ${ }^{-1}$, corroborating the data from this study (Table 2).

The control at 28 DAA was excellent in all herbicide treatments with control levels above $99 \%$, except for the metsulfuron-methyl herbicide applied in resistant biotypes, in which the control levels were of $4 \%$ and $5 \%$ for $\mathrm{B}_{4}$ and $\mathrm{B}_{13}$, respectively (Table 2). Similar results were diagnosed in resistant biotypes of $R$. raphanistrum, where the application of mestulfuron-methyl did not enable the appropriate control (Costa \& Rizzardi, 2013). In the wheat crop, the application of metribuzin, bentazon and 2,4-D amine in postemergence is an option for the management of resistant radish, because they are herbicides selective to the crop and allow an appropriate control (Table 2). Results show that 2,4-D amine in the dosage of $670 \mathrm{~g}$ a.e. ha $\mathrm{h}^{-1}$ is highly efficient in the control of radish biotypes (Farinelli et al., 2005).

For the SDM accumulation variable, evaluated at $28 \mathrm{DAA}$, the reduction was superior to $80 \%$ in the biotypes of $R$. sativus, resistant and susceptible in all herbicide treatments, except in the application of metsulfuron-methyl in the $\mathrm{B}_{4}$ e $\mathrm{B}_{13}$ biotypes in which the reduction was null and inferior to
$21 \%$, respectively (Table 2), possibly related to biotypes sensitivity differences. Costa \& Rizzardi (2013) reported that the application of metsulfuron-methyl causes a small

Table 2 - Control (\%) (A) and shoot dry matter (SDM in g per plant) of biotypes of Raphanus sativus susceptible $\left(\mathrm{B}_{1}\right)$ and resistant $\left(\mathrm{B}_{4}\right.$ and $\left.\mathrm{B}_{13}\right)$ to iodosulfuron at 14 and 28 days after application of the treatments (DAA) with alternative herbicides for the wheat crop management. Capão do LeãoRS, 2014

\begin{tabular}{|c|c|c|c|}
\hline \multirow{2}{*}{ Treatment } & \multicolumn{3}{|c|}{14 DAA } \\
\hline & $\mathrm{B}_{1}$ & $\mathrm{~B}_{4}$ & $\mathrm{~B}_{13}$ \\
\hline Ammonium-glufosinate & $98^{\mathrm{ns}} \mathrm{A}$ & $98 \mathrm{~A}$ & $97 \mathrm{~A}$ \\
\hline Diuron + paraquat & $100{ }^{\mathrm{ns}} \mathrm{A}$ & $100 \mathrm{~A}$ & $100 \mathrm{~A}$ \\
\hline Paraquat & $100{ }^{\mathrm{ns}} \mathrm{A}$ & $100 \mathrm{~A}$ & $100 \mathrm{~A}$ \\
\hline Glyphosate & $98^{\mathrm{ns}} \mathrm{A}$ & $97 \mathrm{~A}$ & $99 \mathrm{~A}$ \\
\hline Saflufenacil & $100^{\mathrm{ns}} \mathrm{A}$ & $100 \mathrm{~A}$ & $100 \mathrm{~A}$ \\
\hline Metribuzin & $99{ }^{\mathrm{ns}} \mathrm{A}$ & $99 \mathrm{~A}$ & $99 \mathrm{~A}$ \\
\hline Bentazon & $100{ }^{\mathrm{ns}} \mathrm{A}$ & $100 \mathrm{~A}$ & $99 \mathrm{~A}$ \\
\hline 2,4-D amine & $98^{\mathrm{ns}} \mathrm{A}$ & $97 \mathrm{~A}$ & $97 \mathrm{~A}$ \\
\hline Metsulfuron-methyl & $90 \mathrm{aB}$ & $5.0 \mathrm{cB}$ & $16 \mathrm{bB}$ \\
\hline Control & $0 .{ }^{\mathrm{ns}} \mathrm{C}$ & $0.0 \mathrm{C}$ & $0.0 \mathrm{C}$ \\
\hline $\mathrm{VC}(\%)$ & \multicolumn{3}{|c|}{1.99} \\
\hline Treatment & \multicolumn{3}{|c|}{$28 \mathrm{DAA}$} \\
\hline Ammonium-glufosinate & $100{ }^{\mathrm{ns}} \mathrm{A}$ & $100 \mathrm{~A}$ & $100 \mathrm{~A}$ \\
\hline Diuron + paraquat & $100^{\mathrm{ns}} \mathrm{A}$ & $100 \mathrm{~A}$ & $100 \mathrm{~A}$ \\
\hline Paraquat & $100{ }^{\mathrm{ns}} \mathrm{A}$ & $100 \mathrm{~A}$ & $100 \mathrm{~A}$ \\
\hline Glyphosate & $99^{\mathrm{ns}} A$ & $100 \mathrm{~A}$ & $100 \mathrm{~A}$ \\
\hline Saflufenacil & $100{ }^{\mathrm{ns}} \mathrm{A}$ & $100 \mathrm{~A}$ & $100 \mathrm{~A}$ \\
\hline Metribuzin & $100^{\mathrm{ns}} \mathrm{A}$ & $100 \mathrm{~A}$ & $100 \mathrm{~A}$ \\
\hline Bentazon & $100{ }^{\mathrm{ns}} \mathrm{A}$ & $100 \mathrm{~A}$ & $100 \mathrm{~A}$ \\
\hline 2,4-D amine & $99{ }^{\mathrm{ns}} \mathrm{A}$ & $100 \mathrm{~A}$ & $100 \mathrm{~A}$ \\
\hline Metsulfuron-methyl & $100 \mathrm{aA}$ & $4.0 \mathrm{bB}$ & $5.0 \mathrm{bB}$ \\
\hline Control & $0.0^{\mathrm{ns}} \mathrm{B}$ & $0.0 \mathrm{C}$ & $0.0 \mathrm{C}$ \\
\hline $\mathrm{VC}(\%)$ & \multicolumn{3}{|c|}{1.25} \\
\hline Treatment & \multicolumn{3}{|c|}{ SDM } \\
\hline Ammonium-glufosinate & $0.19^{\mathrm{ns}} \mathrm{BC}$ & $0.25 \mathrm{C}$ & $0.26 \mathrm{C}$ \\
\hline Diuron + paraquat & $0.15^{\mathrm{ns}} \mathrm{C}$ & $0.17 \mathrm{C}$ & $0.25 \mathrm{C}$ \\
\hline Paraquat & $0.18^{\mathrm{ns}} \mathrm{BC}$ & $0.20 \mathrm{C}$ & $0.24 \mathrm{C}$ \\
\hline Glyphosate & $0.19 \mathrm{bBC}$ & $0.25 \mathrm{bC}$ & $0.33 \mathrm{aC}$ \\
\hline Saflufenacil & $0.18 \mathrm{bBC}$ & $0.24 \mathrm{bC}$ & $0.30 \mathrm{aC}$ \\
\hline Metribuzin & $0.19 \mathrm{bBC}$ & $0.29 \mathrm{aC}$ & $0.32 \mathrm{aC}$ \\
\hline Bentazon & $0.17 \mathrm{bBC}$ & $0.23 \mathrm{bC}$ & $0.52 \mathrm{aB}$ \\
\hline 2,4-D amine & $0.20 \mathrm{bBC}$ & $0.32 \mathrm{aC}$ & $0.37 \mathrm{aC}$ \\
\hline Metsulfuron-methyl & $0.31 \mathrm{cBC}$ & $2.34 \mathrm{aA}$ & $1.58 \mathrm{bA}$ \\
\hline Control & $1.01^{\mathrm{ns}} \mathrm{A}$ & $1.69 \mathrm{~B}$ & $1.76 \mathrm{~A}$ \\
\hline $\mathrm{VC}(\%)$ & \multicolumn{3}{|c|}{26.70} \\
\hline
\end{tabular}

Averages followed by the same lower case letter (on the row) and the same upper case letter (on the column) do not differ significantly among themselves by the Duncan test $(\mathrm{p} \leq 0.05)$. ${ }^{\mathrm{ns}}=$ non-significant $(\mathrm{p} \leq 0.05)$. 
reduction of SDM in resistant biotypes, and it is not considered a management option. Thus, the application of alternative herbicides recommended in the desiccation and in postemergence selective to wheat, such as metribuzin, bentazon and 2,4-D amine is considered an option for the resistant radish management, because they cause a reduction of more than $70 \%$ of the SDM (Table 2).

Regarding the management in desiccation in the crops of corn, glufosinate-ammonium, paraquat, diuron + paraquat, glyphosate and saflufenacil are options for the control of resistant radish, with levels superior to $98 \%$ at 14 DAA (Table 3). In a paper conducted in biotypes of $R$. raphanistrum that the application of glyphosate in desiccation, in the dosage of $720 \mathrm{~g}$ a.e. ha ${ }^{-1}$, provided $98 \%$ of control, corroborating the results obtained in this study (Vitorino et al., 2014). Furthermore, ammonium-glufosinate and glyphosate may also be used in the control of radish in corn postemergence, in case the producer uses a Liberty Link ${ }^{\circledR}$ or Roundup Ready ${ }^{\circledR}$ cultivar (Bohm et al., 2011).

At 28 DAA, the control of resistant radish was excellent for all the herbicides indicated for corn crops, except nicosulfuron, in which the control was below $2 \%$ in biotypes $\mathrm{B}_{4}$ and $\mathrm{B}_{13}$, not being different from the control without the application of herbicide (Table 3). The use of mesotrione, tembotrione and atrazine provided control above $99 \%$ in resistant biotypes, showing themselves as excellent alternatives for the management in crop postemergence (Table 3). However, it is observed that the application of nicosulfuron did not control the biotypes resistant to iodosulfuron, possibly because they belong to the same group in the chemical class. Therefore, the use of herbicides with alternative action mechanisms on corn crops composes a highly efficient strategy in the control of resistant biotypes.

The results of SDM accumulation at 28 DAA showed that all tested herbicides caused a reduction of the SDM in resistant and susceptible biotypes, except nicosulfuron applied on resistant biotypes $\left(\mathrm{B}_{4}\right.$ and $\left.\mathrm{B}_{13}\right)$ where, there was no reduction of the SDM, and did not differ from the control without application (Table 3). Similar results were found in biotypes of radish resistant to inhibitors of ALS, where the application of $22.5 \mathrm{~g}$ a.i. ha $\mathrm{h}^{-1}$ of nicosulfuron provided a

Table 3 - Control (\%) and shoot dry matter (SDM in g per plant) of biotypes of Raphanus sativus susceptible $\left(\mathrm{B}_{1}\right)$ and resistant $\left(\mathrm{B}_{4}\right.$ and $\left.\mathrm{B}_{13}\right)$ to iodosulfuron at 14 and 28 days after application of the treatments (DAA) with alternative herbicides for the corn crop management. Capão do LeãoRS, 2014

\begin{tabular}{|c|c|c|c|}
\hline \multirow{2}{*}{ Treatment } & \multicolumn{3}{|c|}{14 DAA } \\
\hline & $\mathrm{B}_{1}$ & $\mathrm{~B}_{4}$ & $\mathrm{~B}_{13}$ \\
\hline Ammonium-glufosinate & $99^{\mathrm{ns}} \mathrm{A}$ & $99 \mathrm{~A}$ & $100 \mathrm{~A}$ \\
\hline Diuron + paraquat & $100{ }^{\mathrm{ns}} \mathrm{A}$ & $100 \mathrm{~A}$ & $100 \mathrm{~A}$ \\
\hline Paraquat & $100{ }^{\mathrm{ns}} \mathrm{A}$ & $100 \mathrm{~A}$ & $100 \mathrm{~A}$ \\
\hline Glyphosate & $98^{\mathrm{ns}} \mathrm{AB}$ & $100 \mathrm{~A}$ & $99 \mathrm{~A}$ \\
\hline Saflufenacil & $100{ }^{\mathrm{ns}} \mathrm{A}$ & $100 \mathrm{~A}$ & $100 \mathrm{~A}$ \\
\hline Mesotrione & $96{ }^{\mathrm{ns}} \mathrm{B}$ & $94 \mathrm{~B}$ & $95 \mathrm{~B}$ \\
\hline Tembotrione & $94 \mathrm{aB}$ & $89 \mathrm{bC}$ & $90 \mathrm{bC}$ \\
\hline Atrazine & $95 \mathrm{bB}$ & $99 \mathrm{aA}$ & $99 \mathrm{aA}$ \\
\hline Nicosulfuron & $91 \mathrm{aC}$ & $1.0 \mathrm{bD}$ & $6.0 \mathrm{bD}$ \\
\hline Control & $0.0^{\mathrm{ns}} \mathrm{D}$ & $0.0 \mathrm{D}$ & $0.0 \mathrm{E}$ \\
\hline $\mathrm{VC}(\%)$ & \multicolumn{3}{|c|}{2.71} \\
\hline Treatment & \multicolumn{3}{|c|}{$28 \mathrm{DAA}$} \\
\hline Ammonium-glufosinate & $100{ }^{\mathrm{ns}} \mathrm{A}$ & $100 \mathrm{~A}$ & $100 \mathrm{~A}$ \\
\hline Diuron + paraquat & $100{ }^{\mathrm{ns}} \mathrm{A}$ & $100 \mathrm{~A}$ & $100 \mathrm{~A}$ \\
\hline Paraquat & $100{ }^{\mathrm{ns}} \mathrm{A}$ & $100 \mathrm{~A}$ & $100 \mathrm{~A}$ \\
\hline Glyphosate & $100{ }^{\mathrm{ns}} \mathrm{A}$ & $100 \mathrm{~A}$ & $100 \mathrm{~A}$ \\
\hline Saflufenacil & $100{ }^{\mathrm{ns}} \mathrm{A}$ & $100 \mathrm{~A}$ & $100 \mathrm{~A}$ \\
\hline Mesotrione & $100^{\mathrm{ns}} \mathrm{A}$ & $100 \mathrm{~A}$ & $100 \mathrm{~A}$ \\
\hline Tembotrione & $100{ }^{\mathrm{ns}} \mathrm{A}$ & $100 \mathrm{~A}$ & $100 \mathrm{~A}$ \\
\hline Atrazine & $99^{\mathrm{ns}} \mathrm{A}$ & $100 \mathrm{~A}$ & $100 \mathrm{~A}$ \\
\hline Nicosulfuron & $100 \mathrm{aA}$ & $0.0 \mathrm{bB}$ & $2.0 \mathrm{bB}$ \\
\hline Control & $0.0^{\mathrm{ns}} B$ & $0.0 \mathrm{~B}$ & $0.0 \mathrm{~B}$ \\
\hline $\mathrm{VC}(\%)$ & \multicolumn{3}{|c|}{0.82} \\
\hline Treatment & \multicolumn{3}{|c|}{ MDMAP } \\
\hline Ammonium-glufosinate & $0.20^{\mathrm{ns}} \mathrm{B}$ & $0.25 \mathrm{~B}$ & $0.26 \mathrm{~B}$ \\
\hline Diuron + paraquat & $0.18^{\mathrm{ns}} \mathrm{B}$ & $0.18 \mathrm{~B}$ & $0.24 \mathrm{~B}$ \\
\hline Paraquat & $0.18^{\mathrm{ns}} \mathrm{B}$ & $0.18 \mathrm{~B}$ & $0.25 \mathrm{~B}$ \\
\hline Glyphosate & $0.19 \mathrm{bB}$ & $0.25 \mathrm{aB}$ & $0.33 \mathrm{aB}$ \\
\hline Saflufenacil & $0.16 \mathrm{bB}$ & $0.24 \mathrm{aB}$ & $0.30 \mathrm{aB}$ \\
\hline Mesotrione & $0.25^{\mathrm{ns}} \mathrm{B}$ & $0.30 \mathrm{~B}$ & $0.29 \mathrm{~B}$ \\
\hline Tembotrione & $0.18 \mathrm{bB}$ & $0.29 \mathrm{aB}$ & $0.32 \mathrm{aB}$ \\
\hline Atrazine & $0.25 \mathrm{bB}$ & $0.34 \mathrm{aB}$ & $0.29 \mathrm{aB}$ \\
\hline Nicosulfuron & $0.24 \mathrm{bB}$ & $1.64 \mathrm{aA}$ & $1.55 \mathrm{aA}$ \\
\hline Control & $1.12^{\mathrm{ns}} \mathrm{A}$ & $1.45 \mathrm{~A}$ & $1.76 \mathrm{~A}$ \\
\hline $\mathrm{VC}(\%)$ & \multicolumn{3}{|c|}{30.60} \\
\hline
\end{tabular}

Averages followed by the same lower case letter (on the row) and the same upper case letter (on the column) do not differ significantly by the Duncan test $(\mathrm{p} \leq 0.05)$. ${ }^{\mathrm{ns}}=$ non-significant $(\mathrm{p} \leq 0.05)$.

Planta Daninha, Viçosa-MG, v. 34, n. 1, p. 151-160, 2016 
reduction of $35 \%$ of the SDM, when compared to the susceptible biotype (Costa \& Rizzardi, 2013). However, because the other herbicides used presented different action mechanisms, they are considered options for the management of radish in the corn crops (Table 3).

For the alternative management in crops of soybean, at $14 \mathrm{DAA}$, it was seen that ammonium-glufosinate, paraquat, diuron + paraquat, glyphosate and saflufenacil showed control superior to $98 \%$, being options for the management of radish in desiccation. In biotypes of $R$. raphanistrum with multiple resistance to herbicides inhibitors of the ALS and EPSPs enzyme, the application of diquat and diuron provided total control in resistant and susceptible biotypes (Ashworth et al., 2014).

At 28 DAA, the level of radish control was above $99 \%$ in all herbicide treatments, except for resistant biotypes treated with herbicides that inhibit the ALS enzyme (Table 4). Among the tested selective herbicides, fomesafen, in the dosage of $250 \mathrm{~g}$ a.i. ha ${ }^{-1}$, was the only one that controlled the resistant biotypes. Among the herbicides that inhibit the ALS enzyme selective to the crop, it was seen a higher level of control when cloransulam-methyl was used in the dosages of $30 \mathrm{~g}$ a.i. ha ${ }^{-1}$, with $58 \%$ and $74 \%$ of the control in the biotypes $B_{4}$ and $\mathrm{B}_{13}$, respectively (Table 4). Similar results were obtained in resistant biotypes of $R$. raphanistrum where the application of chlorsulfuron, imazamox and metosulam did not provide an efficient control (Yu et al., 2012).

For the SDM variable at 28 DAA, all herbicides with different mechanism enabled a lower accumulation of dry matter in resistant biotypes $\left(\mathrm{B}_{4}\right.$ and $\left.\mathrm{B}_{13}\right)$, with reduction above $72 \%$ and $80 \%$, respectively (Table 4 ). These results corroborate the ones obtained by Costa $\&$ Rizzardi (2013) where no herbicide inhibitor of the ALS enzyme provided efficient control in biotypes of resistant radish, suggesting that the biotypes presented crossed-resistance.

\section{Crossed resistance}

Through the variance analysis, an interaction was seen among the biotype factors and the tested herbicides inhibitors of the ALS enzyme. At 28 DAA, the control was above $98 \%$ in the susceptible biotype $\left(\mathrm{B}_{1}\right)$ and below $11 \%$ in the biotypes $\mathrm{B}_{4}$ and $\mathrm{B}_{13}$ when there was use of iodosulfuron, metsulfuron-methyl,

Table 4 - Control (\%) and shoot dry matter (SDM in g per plant) of biotypes of Raphanus sativus susceptible $\left(\mathrm{B}_{1}\right)$ and resistant $\left(\mathrm{B}_{4}\right.$ and $\left.\mathrm{B}_{13}\right)$ to iodosulfuron at 14 and 28 days after application of the treatments (DAA) with alternative herbicides for the soybean crop management. Capão do Leão-RS, 2014

\begin{tabular}{|c|c|c|c|}
\hline \multirow{2}{*}{ Treatment } & \multicolumn{3}{|c|}{$14 \mathrm{DAA}$} \\
\hline & $\mathrm{B}_{1}$ & $\mathrm{~B}_{4}$ & $\mathrm{~B}_{13}$ \\
\hline Ammonium-glufosinate & $99^{\mathrm{ns}} \mathrm{A}$ & $99 \mathrm{~A}$ & $100 \mathrm{~A}$ \\
\hline Diuron + paraquat & $100{ }^{\mathrm{ns}} \mathrm{A}$ & $100 \mathrm{~A}$ & $100 \mathrm{~A}$ \\
\hline Paraquat & $100{ }^{\mathrm{ns}} \mathrm{A}$ & $100 \mathrm{~A}$ & $100 \mathrm{~A}$ \\
\hline Glyphosate & $98^{\mathrm{ns}} \mathrm{A}$ & $100 \mathrm{~A}$ & $99 \mathrm{~A}$ \\
\hline Saflufenacil & $100{ }^{\mathrm{ns}} \mathrm{A}$ & $100 \mathrm{~A}$ & $100 \mathrm{~A}$ \\
\hline Clorimuron & $64 \mathrm{aC}$ & $15 \mathrm{bC}$ & $20 \mathrm{bC}$ \\
\hline Fomesafen & $100^{\mathrm{ns}} \mathrm{A}$ & $100 \mathrm{~A}$ & $100 \mathrm{~A}$ \\
\hline Imazethapyr & $66 \mathrm{aC}$ & $12 \mathrm{bC}$ & $8.0 \mathrm{bC}$ \\
\hline Cloransulan & $91 \mathrm{aB}$ & $60 \mathrm{bB}$ & $56 \mathrm{bB}$ \\
\hline Control & $0.0^{\mathrm{ns}} \mathrm{D}$ & $0.0 \mathrm{D}$ & $0.0 \mathrm{D}$ \\
\hline $\mathrm{VC}(\%)$ & \multicolumn{3}{|c|}{2.93} \\
\hline Treatment & \multicolumn{3}{|c|}{28 DAA } \\
\hline Ammonium-glufosinate & $100{ }^{\mathrm{ns}} \mathrm{A}$ & $100 \mathrm{~A}$ & $100 \mathrm{~A}$ \\
\hline Diuron + paraquat & $100^{\mathrm{ns}} \mathrm{A}$ & $100 \mathrm{~A}$ & $100 \mathrm{~A}$ \\
\hline Paraquat & $100^{\mathrm{ns}} \mathrm{A}$ & $100 \mathrm{~A}$ & $100 \mathrm{~A}$ \\
\hline Glyphosate & $100{ }^{\mathrm{ns}} \mathrm{A}$ & $100 \mathrm{~A}$ & $100 \mathrm{~A}$ \\
\hline Saflufenacil & $100{ }^{\mathrm{ns}} \mathrm{A}$ & $100 \mathrm{~A}$ & $100 \mathrm{~A}$ \\
\hline Clorimuron & $99 \mathrm{aA}$ & $20 \mathrm{bC}$ & $25 \mathrm{bC}$ \\
\hline Fomesafen & $100{ }^{\mathrm{ns}} \mathrm{A}$ & $100 \mathrm{~A}$ & $100 \mathrm{~A}$ \\
\hline Imazethapyr & $100 \mathrm{aA}$ & $2.0 \mathrm{bD}$ & $0.0 \mathrm{bD}$ \\
\hline Cloransulan & $100 \mathrm{aA}$ & $58 \mathrm{cB}$ & $74 \mathrm{bB}$ \\
\hline Control & $0.0^{\mathrm{ns}} \mathrm{B}$ & $0.0 \mathrm{D}$ & $0.0 \mathrm{D}$ \\
\hline $\mathrm{VC}(\%)$ & \multicolumn{3}{|c|}{2.37} \\
\hline Treatment & \multicolumn{3}{|c|}{$\overline{\text { MDMAP }}$} \\
\hline Ammonium-glufosinate & $0.20{ }^{\mathrm{ns}} \mathrm{B}$ & $0.25 \mathrm{C}$ & $0.26 \mathrm{C}$ \\
\hline Diuron + paraquat & $0.18^{\mathrm{ns}} \mathrm{B}$ & $0.18 \mathrm{C}$ & $0.24 \mathrm{C}$ \\
\hline Paraquat & $0.18^{\mathrm{ns}} \mathrm{B}$ & $0.18 \mathrm{C}$ & $0.25 \mathrm{C}$ \\
\hline Glyphosate & $0.19 \mathrm{bB}$ & $0.25 \mathrm{aC}$ & $0.33 \mathrm{aC}$ \\
\hline Saflufenacil & $0.16 \mathrm{bB}$ & $0.24 \mathrm{aC}$ & $0.30 \mathrm{aC}$ \\
\hline Clorimuron & $0.29 \mathrm{bB}$ & $1.47 \mathrm{aA}$ & $1.43 \mathrm{aA}$ \\
\hline Fomesafen & $0.17 \mathrm{bB}$ & $0.40 \mathrm{aC}$ & $0.28 \mathrm{aC}$ \\
\hline Imazethapyr & $0.24 \mathrm{bB}$ & $1.51 \mathrm{aA}$ & $1.42 \mathrm{aA}$ \\
\hline Cloransulan & $0.29 \mathrm{bB}$ & $0.80 \mathrm{aB}$ & $0.66 \mathrm{aB}$ \\
\hline Control & $1.12^{\mathrm{ns}} \mathrm{A}$ & $1.45 \mathrm{~A}$ & $1.76 \mathrm{~A}$ \\
\hline $\mathrm{VC}(\%)$ & \multicolumn{3}{|c|}{30.60} \\
\hline
\end{tabular}

Averages followed by the same lower case letter (on the row) and the same upper case letter (on the column) do not differ significantly among themselves by the Duncan test $(\mathrm{p} \leq 0.05)$. ${ }^{\mathrm{ns}}=$ non-significant $(\mathrm{p} \leq 0.05)$. 
flucarbazone-sodium, imazethapyr and cloransulam-methyl (Table 5). Among the herbicides that inhibit the ALS enzyme, bispyribac-sodium was the one that provided a higher level of control, with $78 \%$ and $68 \%$ in the biotypes $\mathrm{B}_{4}$ and $\mathrm{B}_{13}$, respectively (Table 5 ). The control differences diagnosed in the resistant biotypes may be related to the differential affinity of the herbicide molecule with the enzyme target-site, due to the possible mutation of the ALS gene (Délye, 2013). Similar results were obtained in biotypes of Xanthium strumarium resistant to herbicides inhibitor of the ALS enzyme, where the resistant biotypes were less sensitive to herbicides of the chemical group of the imidazolinones, when compared to herbicides of the group of the sulfonylureas and triazolopyrimidines (Schmitzer et al., 1993).

Regarding the SDM accumulated by biotypes, it was observed that the application of herbicides in the recommended doses reduced around $70 \%$ of the $\mathrm{SDM}$ of $\mathrm{B}_{1}$, when compared to the control without application (Table 5). For the resistant biotypes, the only herbicide that caused reduction of the SDM was bispyribac-sodium, in which there was a reduction of $35 \%$ and $60 \%$ of the SDM in the biotypes $B_{4}$ and $B_{13}$, respectively, when compared to their respective controls (Table 5). A similar result was found in resistant biotypes of $R$. raphanistrum, where the accumulation of the SDM was different among herbicides inhibitors of the ALS enzyme and greater when cloransulam-methyl was used in the dosage of $30 \mathrm{~g}$ a.i. ha ${ }^{-1}$, with a reduction of $61 \%$ when compared to the control without application (Costa \& Rizzardi, 2013).

The results showed that the radish biotype $B_{1}$ is susceptible, while biotypes $B_{4}$ and $B_{13}$ are resistant to iodosulfuron. The results proved that there was no efficient control with any of the herbicides that inhibit the ALS enzyme due to the existence of crossed resistance. To the resistant biotypes control it's recommended the use of ammonium-glufosinate, glyphosate, diuron+paraquat, paraquat and saflufenacil in dessecation. The selective herbicides metribuzin, bentazon and 2,4-D amine in wheat; mesotrione, tembotrione and atrazine in corn; and fomesafen in soybean are also options for resistant biotypes management.
Table 5 - Control (\%) and SDM (per plant) of biotypes of Raphanus sativus susceptible $\left(\mathrm{B}_{1}\right)$ and resistant $\left(\mathrm{B}_{4}\right.$ and $\left.\mathrm{B}_{13}\right)$ to iodosulfuron submitted to different chemical groups inhibitors of the ALS enzyme at 28 days after application of the treatments (DAA). Capão do Leão-RS, 2014

\begin{tabular}{|l|c|c|c|}
\hline \multirow{2}{*}{\multicolumn{1}{|c|}{ Treatment }} & \multicolumn{3}{|c|}{$28 \mathrm{DAA}$} \\
\cline { 2 - 4 } & $\mathrm{B}_{1}$ & $\mathrm{~B}_{4}$ & $\mathrm{~B}_{13}$ \\
\hline Metsulfuron-methyl & $99 \mathrm{aA}$ & $2.0 \mathrm{bCD}$ & $2.0 \mathrm{bC}$ \\
\hline Iodosulfuron & $99 \mathrm{aA}$ & $1.0 \mathrm{bCD}$ & $4.0 \mathrm{cB}$ \\
\hline Flucarbazone & $98 \mathrm{aA}$ & $0.0 \mathrm{bD}$ & $4.0 \mathrm{bB}$ \\
\hline Imazethapyr & $98 \mathrm{aA}$ & $3.0 \mathrm{bC}$ & $2.0 \mathrm{bC}$ \\
\hline Bispyribac-sodium & $99 \mathrm{aA}$ & $78 \mathrm{bA}$ & $68 \mathrm{cA}$ \\
\hline Cloransulam-methyl & $99 \mathrm{aA}$ & $10 \mathrm{bB}$ & $11 \mathrm{bB}$ \\
\hline Control & $0.0{ }^{\mathrm{ns}} \mathrm{B}$ & $0.0 \mathrm{D}$ & $0.0 \mathrm{D}$ \\
\hline VC (\%) & \multicolumn{3}{|c|}{7.00} \\
\hline \multicolumn{1}{|c|}{ Treatment } & $\mathrm{MDMAP}$ \\
\hline Metsulfuron-methyl & $0.50 \mathrm{bB}$ & $1.31 \mathrm{aAB}$ & $1.41 \mathrm{aBC}$ \\
\hline Iodosulfuron & $0.43 \mathrm{bB}$ & $1.41 \mathrm{aAB}$ & $1.51 \mathrm{aAB}$ \\
\hline Flucarbazone & $0.44 \mathrm{bB}$ & $1.37 \mathrm{aAB}$ & $1.82 \mathrm{aA}$ \\
\hline Imazethapyr & $0.38 \mathrm{bB}$ & $1.59 \mathrm{aA}$ & $1.40 \mathrm{aBC}$ \\
\hline Bispyribac-sodium & $0.42 \mathrm{bB}$ & $0.75 \mathrm{aC}$ & $0.58 \mathrm{abD}$ \\
\hline Cloransulan-methyl & $0.43 \mathrm{bB}$ & $1.22 \mathrm{aB}$ & $1.06 \mathrm{bC}$ \\
\hline Control & $1.42^{\mathrm{ns}} \mathrm{A}$ & $1.15 \mathrm{~B}$ & $1.42 \mathrm{BC}$ \\
\hline VC (\%) & & 14.63 \\
\hline
\end{tabular}

Averages followed by the same lower case letter (on the row) and the same upper case letter (on the column) do not differ significantly among themselves by the Duncan test $(\mathrm{p} \leq 0.05)$. $\mathrm{ns}=$ non-significant $(\mathrm{p} \leq 0.05)$.

\section{ACKNOWLEDGMENTS}

We thank the coordination of the Higher Education Personnel Training (CAPES) for the scholarship to the first author and also the Embrapa/Monsanto Partnership.

\section{LITERATURE CITED}

AGOSTINETTO, D. et al. Desempenho de formulações e doses de glyphosate em soja transgênica. R. Trópica, v. 3, n. 2, p. 36, 2009.

\section{AGROFIT. Sistema de agrotóxicos fitossanitários.} Available at: $<$ http://extranet.agricultura.gov.br/agrofitcons/ principal_agrofit_cons $>$. Accessed on: 8 sept. 2015.

ASHWORTH, M. B. et al. Identification of the first glyphosate-resistant wild radish (Raphanus raphanistrum L.) populations. Pest. Manage. Sci., v. 70, n. 9, p. 1432-1436, 2014.

Planta Daninha, Viçosa-MG, v. 34, n. 1, p. 151-160, 2016 
BALBINOT JR., A. A. et al. Efeito de coberturas de inverno e sua época de manejo sobre a infestação de plantas daninhas na cultura de milho. Planta Daninha, v. 25, n. 3, p. 473-480, 2007.

BIANCHI, M. A. et al. Interferência de Raphanus sativus na produtividade de cultivares de soja. Planta Daninha, v. 29, n. 4, p. 7 83-792, 2011.

BOHM, G. M. B. et al. Controle de plantas daninhas, biomassa e metabolismo microbiano do solo em função da aplicação de glifosato ou imazetapir na cultura da soja. Semina: Ci. Agr., v. 32, n. 3, p. 919-930, 2011.

CHRISTOFFOLETI, P. J. Curvas de dose-resposta de biótipos resistente e suscetível de Bidens pilosa L. aos herbicidas inibidores da ALS. Sci. Agr., v. 59, n. 3, p. 513-519, 2002.

COSTA, L. O.; RIZZARDI, M. A. Herbicidas alternativos para o controle de Raphanus raphanistrum L. resistente ao herbicida metsulfurom-metílico. R. Bras. Herbic., v. 12, n. 3, p. 268-276, 2013.

DÉLYE, C. Unravelling the genetic bases of non-target-sitebased resistance (NTSR) to herbicides: a major challenge for weed science in the forthcoming decade. Pestic. Manage Sci., v. 69, n. 2, p. 176-187, 2013.

DUGGLEBY, R. G. et al. Structure and mechanism of inhibition of plant acetohydroxyacid synthase. Plant Physiol. Biochem., v. 46, n. 3, p. 309-324, 2008.

FARINELLI, R. et al. Eficiência do herbicida 2,4-D no controle de Raphanus sativus L., em pós-emergência na cultura de milheto. R. Bras. Milho Sorgo, v. 4, n. 1, p. 104-111, 2005.

FRANS, R.; CROWLEY, H. Experimental design and techniques for measuring and analyzing plant responses to weed control practices. In: CAMPER, N. D. (Ed.). Research methods in weed science. 3.ed. Champaign: Southern Weed Science Society, 1986. 37 p.

HEAP, I. The international survey of herbicide resistant weeds. Available at: $<$ http://www.weedscience.org $>$. Accessed on: 8 sept 2015 .
MONJARDINO, M. et al. Multispecies resistance and integrated management: abioeconomic model for integrated management of rigid ryegrass (Lolium rigidum) and wild radish (Raphanus raphanistrum). Weed Sci., v. 51, n. 5, p. 798-809, 2003.

OLIVEIRA NETO, M. et al. Estratégias de manejo de inverno e verão visando ao controle de Conyza bonariensis e Bidens pilosa. Planta Daninha, v. 28, n. 4, p. 1107-1116, 2010.

PANDOLFO, C. E. et al. Limited occurrence of resistant radish (Raphanus sativus) to Ahas-inhibiting herbicides in Argentina. Planta Daninha, v. 31, n. 3, p. 657-666, 2013

SCHMITZER, P. R. et al. Lack of cross-resistance of imazaquin resistant Xanthium strumarium acetolactate synthase to flumetsulam and chlorimuron. Plant Physiol., v. 103, n. 1, p. 281-283, 1993.

SEEFELDT, S. S. et al. Log-logistic analysis of herbicide dose-response relationships. Weed Technol., v. 9, n. 2, p. 218-227, 1995.

\section{SIGMAPLOT - Scientific Graphing Software. Version} 12.0. 2012.

VARGAS, L.; ROMAM, E. S. Seletividade e eficiência de herbicidas em cereais de inverno. R. Bras. Herbic., v. 1, n. 3, p. 1-10, 2005.

VARGAS, L.; SILVA, A. A.; AGOSTINETTO, D.; GAZZIERO, D. Resistência de plantas daninhas a herbicidas. In: AGOSTINETTO, R.; VARGAS, L. (Ed). Resistência de plantas daninhas a herbicidas no Brasil. Passo Fundo: Berthier, 2009. 350 p.

VITORINO, H. S. et al. Eficácia de herbicidas na dessecação de nabiça e sua ação na germinação de sementes, Semina: Ci. Agr., v. 35, n. 3, p. 1119-1128, 2014.

WALSH, M. J. et al. Frequency and distribution of herbicide resistance in Raphanus raphanistrum populations randomly collected across the Western Australian wheatbelt.

Weed Res., v. 47, n. 6, p. 542-550, 2007.

YU, Q. et al. Resistance evaluation for herbicide resistanceendowing acetolactate synthase (ALS) gene mutations using Raphanus raphanistrum populations homozygous for specific ALS mutations. Weed Res., v. 52, n. 2, p. 178-186, 2012. 